\title{
A Case Study of the Linguistic Variety of Women in the Mawelawela Correctional Institution, Swaziland
}

\author{
Lindiwe Simelane \\ Department of Instructional Design and Development, Faculty of Institute of Distance Education, University of Swaziland, Swaziland
}

Copyright $(2016$ by authors, all rights reserved. Authors agree that this article remains permanently open access under the terms of the Creative Commons Attribution License 4.0 International License

\begin{abstract}
This paper examines the use of a lexical variety used by women prisoners in Swaziland. It analyses whether women prisoners living as a community manipulate language to encode their own terminology in order to remain separate from the dominant society and use expressions that may never be understood by the outside world. The study used the qualitative research design which enabled the researcher to examine the problem from the participants' perspective. It was based at Mawelawela Correctional Institution the only women prison in Swaziland. Data was gathered through the semi-structured face-to-face focus group interview. The interview findings demonstrate that women prisoners coin terminology so that warders, police officers and people from outside the prison will not understand their conversations. They do this mainly to preserve the culture of distancing themselves from the prison authorities, and maintain a distinct linguistic identity. The results of the study suggest that language change has allowed people to manipulate language and even reveal ways in which they use it to encode and have some sort of identity. The interview revealed their attitudes about prison life. They borrow words from other languages to code their language, and also clip words by either cutting the initial part or both the initial and final part of the word. It also discovered that the prisoners use words metaphorically.
\end{abstract}

Keywords Linguistic Variety, Lexical Variety, Linguistic Distinctiveness, Attitudinal Expressions, Social Marker

\section{Introduction}

Languages are dynamic and change over time. Language change has allowed people to manipulate language and even reveal ways in which they use it to encode and have some sort of identity. Prisoners live in a community and manipulate language to encode their own terminology to "remain separate from the dominant society" according to Johnson-Weiner [1] and they have expressions that may never be understood by the outside world. Benton [2] argues that "the speech of the contemporary criminal culture has always been a rich source of colour and vitality to any language." Prisoners coin terminology so that people like warders, police officers and even people from outside prison will not understand their speech. The words vary from prison to prison and cannot be absolute.

Swaziland is a landlocked Kingdom located in the south-eastern part of Africa. There are two official languages spoken in Swaziland, i.e. English and SiSwati. SiSwati is the most spoken language as it is the mother tongue for almost all Swazis. English is used as the medium of instruction in schools and in business; it is mostly spoken by the elite. Swaziland is a one ethnic group society. Even so, some varieties within the SiSwati language still exist. There are varieties such as the 'Thithiza' and 'Yeyeza' varieties spoken in the south and eastern regions respectively. SiSwati can be divided into two categories, i.e. 'Standard SiSwati' and 'other.' In Swaziland Standard SiSwati is considered to be 'purer' as it is not heavily influenced by the Zulu language, which falls under the 'other' category. Standard SiSwati is mainly spoken in the northern, central and southwest regions of Swaziland.

In the only female prison in Swaziland, most prisoners speak SiSwati as their first language. Although they are SiSwati speakers, the fact that they are confined to one place, has made it possible for them to develop a variety which is different from the Standard variety. It is in this regard that the research was carried out to find out if and to what extent the lexical items in women prisoners' speech differ from those of the Standard variety in Swaziland.

\subsection{Lexical Items and Speech Communities}

According to Fromkin et al [12], lexical items “... are meaningful linguistic units that can be combined to form phrases and sentences." The Swaziland Prisoners, as a social group, have a variety of their own which they use to communicate among themselves. Using this variety has allowed them to become a speech community. Speech communities according to Saville-Troike [13] consist of 
people "who have something in common". In other words, in the case of these women prisoners, as a group they have something in common that they are now confined in one place because of the crimes they committed, and because they share the same language they have coded, they are able to communicate shared meaning and shared beliefs. Macelhearn [14] posits that when people share the same language, they are able to discuss things among themselves.

A study conducted by Milroy \& Milroy [15] on three close-knit lower working class communities in Belfast tried to establish if social networks could clarify the differences between men and women speech. Their findings were that the vernacular form "is associated with the speaker's degree of integration into the community's social network." According to Deumert \& Mesthrie [16] social network refers to "the informal and formal social relationships that individuals maintain with one another". One of the two criteria they use to describe networks is the network density. They assert that in a high-density network "the members of the network are known to each other and interact with each other regularly"

Although the researcher draws largely on the Belfast study, this study will focus on the close-knittedness of communities and the way prisoners interact. In Gumperz' terms, this kind of interaction would be the 'closed' type of network where the "individuals share a number of communicative preferences" [15]. This is because there is no doubt that prisoners too belong to a close-knit community. The fact that they have been removed from their people and from familiar environments, and have been placed in a confined situation illustrates this. They also fall in the category of high-density network. This is because they are members of a particular social network and communicate regularly with each other. Since Mawelawela prison is not a big institution, the prisoners are likely to know one another and interact regularly. When they communicate among themselves they form their own network because they know each other well.

\subsection{Language Variation}

Change can occurs in various language variables. The issue of linguistic variation has been a major focus of sociolinguists for some decades now. Linguistic variation usually manifests either geographically or socially in society $[3,4]$. Scholars agree that linguistic variations are the result of various factors such as Social Stratification [5], Gender [6-7], Patterns of Interaction [8], Respect and Politeness [9-10], Gender and Politeness [11].

Labov [3], in the Martha's Vineyard study, mainly looked at the language variation patterns in that community. In fact, he worked in particular on the shift in the pronunciation of the diphthongs [ai] and [au] among the people of this island. Labov found that the use of these diphthongs was common among the youth rather than among the older people. Instead the old Vineyarders maintained the mainstream pronunciation. Fischer (1958) in [17] studied a school in
England to determine the use of /-ing/ and /-in/ variables among boys and girls. For example, the variable /-ing/ is found in words like 'studying', 'dancing', etc. and /-in/ in words like 'eatin,', 'jumpin', etc. Fischer contends that such differences of pronunciation in one language may be carried by the fact that:

people adopt a variant not because it is easier to pronounce... but because it expresses how they feel about their relative status versus other conversants; [this] remain[s] a central tenet of variationists sociolinguistics

According to Coupland et al.[18], this suggests that speakers of a language "are able to modify language (and other behavioural differences) to decrease or increase difference".

\subsection{Gender and Language}

The study conducted by Finlayson [9] among Xhosa women in South Africa reveals that the Xhosa women to a larger extent use codes in their language. Finlayson found that Xhosa women, due to respect, could not call their in-laws, especially their father-in-laws, by name. They even use other syllables to try and avoid the pronunciation of syllables that appear in the names of their in-laws. They either substitute the syllable with a synonym or use one that can be closer in meaning to the actual syllable. This avoidance system results in word coding. Prisoners likewise coin new words. What needs be mentioned here is that the difference between the way Xhosa women and prisoners code words is that the prison code is used to avoid being intelligible to outsiders, whereas the Xhosa women use codes to show respect.

As a networked group, the prisoners also use a great deal of code switching. They code switch so that outsiders generally do not have access to what they mean [20]. Because the Swazi women prisoners have the advantage of knowing both the Standard variety and the 'other' variety, they are able to codeswitch when they interact among themselves. However, when they converse with warders or prison authorities they switch to Standard SiSwati. What is code switching then? According to Scotton \& Ury [19] code switching refers to "the use of two or more linguistic varieties in the same conversation or interaction..." Finlayson and Slabbert [20] contend that code switching is the "means of accommodation or meeting each other halfway." This means that when people code switch they do it to accommodate their addressees in the conversation.

Code switching is a social process of speech communities, and therefore, one needs to understand why and when people code switch. In the case of prisoners, they code switch because they want to use a covert code that communities, especially those who look after them in prison and people from the outside will not understand.

Trudgill [21] in his study closely examined the Koasati 
men and women speech and claims that women's speech retains historically older forms of language than in men's speech. With careful examination of these prisoners' language it can be seen that his claim is not universally applicable because women prisoners use the Non-Standard forms of language and are intelligible when they interact. It can, however, be said that these prisoners when they were still outside prison may have maintained the Standard form, but because they are now in prison, they use the Non-Standard form.

The study was motivated by a set of observations. First, the researcher observed that, when some prisoners are freed, and begin to function in a larger society, the kind of lexical items they use are quite different from the SiSwati Standard variety. Some of the freed prisoners continue to use the linguistic code that they were using in prison. This makes their speech different from that of non-prisoners. For instance, the SiSwati name for 'breasts' is 'emabele' but the prisoners' code name is 'parmalat., ${ }^{1}$ The researcher also observed that their pattern of interaction with people is different and this probably affects the way they speak.

The above observations were a result of an investigation that looked at:

- The specific terms found in Swazi women prisoners' language.

- The provision of an account of this kind of linguistic variation.

- The ways in which women prisoners' language differs from the Standard language.

\section{Methods and Materials}

\subsection{The Research Site}

The study was carried out at the Mawelawela Women Central Prison, the only women-only prison in Swaziland. It should be noted that the number of inmates often changes because some prisoners are brought in once they are convicted and others are then released to give space to the newcomers. The number has therefore not been stable for a long time. At the time the study was conducted the prison had about 100 inmates. Another reason why the number of inmates keeps on changing is because once the other remand centres are overpopulated, the prisoners are transferred to Mawelawela.

\subsection{The Informants}

The informants who participated in this study were twenty women prisoners who had spent at least two in prison. Their age ranged from 16 to 41 years. It was discovered that some of the prisoners had had some form of education but for some reasons dropped out of school. Out of the twenty prisoners, only one had never attended school. The highest Standard

1 'parmalat' is a brand of dairy products (see Table 1 in appendices) reached was Form 5 (one prisoner). The twenty women were chosen for the study because they had spent a reasonable time in prison and were overheard using the lexical items in which the researcher was interested. These prisoners were divided into groups of five. The reasons behind the grouping of these prisoners were mainly two:

- Time constraints encountered by the researcher.

- More importantly was the fact that these prisoners discuss and interact better when they are in groups than in an individual interview situation

\subsection{Procedure and Material}

The elicitation instrument that was used for this study was the semi-structured face-to-face focus group interview. This type of interview gave the researcher insights into the subjects' interpretation of their code.

The interview was used because it allowed direct interaction with the respondents. It also allowed the interviewer to probe further and ask for clarity where interesting issues emerged during the interview. In addition, it allowed the voicing of opinions without fear of prejudice or bias.

\subsubsection{The Interview}

The interview was a combination of closed and open-ended questions. Before the interview, the following research objectives were briefly explained to the informants:

- In what ways is the language of women prisoners different from the Standard language/Standard variety of the Swazi people?

- What are the specific terms found in the language of these prisoners?

- How do we account for this kind of linguistic variation?

The interview was divided into two parts. The first part required the selected inmates to give their personal data and some information regarding their attitude about prison. For this section the inmates were divided into groups of five. The researcher verbally asked the questions and wrote down the answers on the interview sheet.

In the second part of the interview certain SiSwati Standard words were prepared and the inmates were required to give the terms they used for each of these words. The words were chosen because they form part of the prison culture, such as words related to everyday routine (i.e. body parts, meals, court register, etc.). Above all, the study sought to establish if there were secret codes used by the prisoners' community to exclude warders and police officers.

\subsection{Data Collection}

The researcher participated in the discussion through careful observation of prisoner interaction. The groups were given about fifteen minutes to answer the first part of the interview questions. The questions were read to the interviewees and answers written down on the interview sheet. The words used were divided into the following 
groups:

(i) body parts

(ii) meals

(iii) hygiene

(iv) relationships

(v) prison facilities

(vi) court registers

(vii) other issues.

\subsection{Ethical Considerations}

Permission to go to the Women prison was requested and obtained from the Commissioner of Prisons. In terms of ethical considerations, the informants were informed that they would remain anonymous and confidentiality would be ensured.

\subsection{Limitations}

The major study limitation was the way the interview was carried out. First, in the interview room beside the informants were two warders who sat quietly in their corner observing and listening to what was discussed. This did not make the interviewees comfortable. Secondly, the prison regulations did not permit the researcher to make recordings of the interview. This proved to be rather distracting too because the interviewer had to write the answers which might have interfered with the validity of the results. It is possible that the interview could have been improved with tape recording, as this would have picked everything the prisoners mentioned.

\subsection{Data Analysis and Discussion of Findings}

In this section, data from the interviews with prisoners was described and analyzed. The data showed that there was linguistic variation and it was categorized in three groups, namely: a) linguistic features of the prison code (metaphors, clippings and others), b) origins of the features and c) attitudinal functions.

For the discussion, it should be noted that words used as examples are drawn from different tables in the appendices. The researcher discovered that there was fluidity in the way the words could be used. For example, the word 'mortuary' could be used metaphorically in one context, and in the other could be used to show the prisoners' attitudinal expression about prison life. For the details of all the words that were discussed with prisoners in this study, the readership will refer to Appendices.

\section{Linguistic Features of Prison Code}

\section{a) Metaphors}

The table below shows metaphorical use of words in the prison code.

\begin{tabular}{|c|c|c|}
\hline Prison Code & SiSwati & English \\
\hline mortuary & lijele & prison \\
tidladla & tandla & hands \\
\hline
\end{tabular}

It was discovered that some words prisoners use have a metaphorical connotation. For example, they use the word 'mortuary' to refer to the prison. A mortuary is a place where dead bodies are kept. When prisoners use this word, they metaphorically mean that they are not comfortable in this place. Because a mortuary is a cold place, it therefore cannot accommodate them. Since the mortuary keeps only dead people, they are 'living dead,' hence they have been cut off from their families, friends, and also the outside world.

Another word that the prisoners use is 'tidlaldla' for 'hands.' This word, even though it is found in the Standard variety, has a metaphorical meaning when used by the prisoners. In SiSwati the word is used for animal paws. The prisoners thus view people even from inside prison, such as the warders, police and society outside prison, as people who see them as animals. While inside prison, the police do not treat them like human beings: the prisoners are made to work very hard as if they are not human beings. When they are outside prison, society does not easily accept them. They therefore refer to themselves as animals with animal features, tidladla.

\section{b) Clippings}

In the table below are examples of clippings of words in the prison code.

\begin{tabular}{|c|c|c|}
\hline Prison code & SiSwati & English \\
\hline hosi & sibhedlela & hospital \\
shu & umshushisi & precutor \\
libhontji & libhontjisi & bean \\
\hline
\end{tabular}

Some words that the prisoners use are not coded as such. The words are shortened to form new words. This is called clipping. According to Aremo [22] clipping is the "process of forming a new item by deleting one or more parts from an established item." The deletion of parts of words can either happen at the initial part, the final part, or can happen at both ends. From the example above we find three words that have been 'clipped' by the prisoners. For example, 'hosi' for 'hospital,' 'shu' for 'prosecutor,' and 'libhontji' for 'beans.' In the first example of 'hosi' the final part, '-pital,' has been deleted. The other example 'shu' comes from the SiSwati word 'umshushisi' and it refers to 'prosecutor.' What has been deleted from this word is both the initial and final part of the word, for example, 'um-' and '-shisi' respectively. It should be noted that from the list of clippings given in the table, the prisoners do not only shorten words from SiSwati but also English words like the word 'hospital.'

In the last example, it is the final part ' $-s i$ ' that has been removed from the SiSwati word 'libhontjisi.' 


\section{c) Miscellaneous}

In this section some other findings are discovered. For example:

\begin{tabular}{|c|c|c|}
\hline Prison Code & SiSwati & English \\
\hline $\begin{array}{l}\text { six-nine } \\
\text { Ngarua/baphatsibemfihlakalo } \\
\text { ema-zero }\end{array}$ & $\begin{array}{l}\text { kuchama } \\
\text { tiboshwa lesetinesikhatsi ejele } \\
\text { emashende }\end{array}$ & $\begin{array}{c}\text { to pee } \\
\text { the judicial } \\
\text { extra-marital partners }\end{array}$ \\
\hline
\end{tabular}

Some studies about prisoners' language, especially in Canada, reveal that prisoners are fond of using numbers as their codes [2]. For example, the prisoners use the numbers '12:01' when referring to the release of a prisoner. For example, 'he was awarded a 12:01 today' [2]. However, in the Swazi examples above, the only numerical the women prisoners use is six- nine (6-9). They use this number when they are referring to 'use the toilet' especially when they want to pee. From the example above and what other studies have revealed, it is clear that the Mawelawela prisoners use words rather than numericals. An assumption that one can make when comparing Canadian and Swazi women prisoners is that the prisoners in Swaziland are not all numerically literate because of their educational backgrounds.

It has been gathered that, even though the prisoners are inside prison, they do follow events that happen outside their territory. They are aware of who did what and when. The long term-servers in this prison are called 'bo-Ngarua'2 (as shown in the example). Because Ngarua was a foreigner and had been a civil servant for a long time, the prisoners found their life similar to his. They have spent a long time in prison and are also foreigners because prison is not their real home. Their life is not different from Ngarua's hence they also call themselves 'baphatsi bemfihlakalo' (the judiciary).

Prisoners can be involved in extra-marital relationships. They call their 'secret lovers' 'ema-zero' as shown in the example above. These partners they have in these relationships are secret and therefore are seen as nonexistent, hence the use of the word 'zero.'

\section{Origins}

It has been observed that there are words that have been borrowed from within SiSwati and others from other languages. With the loan words there are three possible origins and these are English, Afrikaans and Shangaan. Other words have been borrowed from Tsotsitaal but we cannot say they originate from Tsotsitaal because research has shown that the Tsotsi language itself has to borrow words from other languages to come into existence.

\section{a) Words borrowed from SiSwati}

The table below shows examples of words borrowed from the SiSwati language.

2 Ngarua was the then Director of Public Prosecutor (DPP) in Swaziland. He was famous for not siding with the King and the Swazi Government, and eventually went against their wishes. He resigned before he was apprehended and deported.

\begin{tabular}{|c|c|c|}
\hline Prison Code & SiSwati & English \\
\hline $\begin{array}{c}\text { makhwapheni } \\
\text { bomshana }\end{array}$ & $\begin{array}{c}\text { umphatsi welijele } \\
\text { bantfwana }\end{array}$ & $\begin{array}{c}\text { officer-in-charge } \\
\text { children }\end{array}$ \\
\hline
\end{tabular}

There are words that have been borrowed from the Siswati language and are used differently by the prisoners. For example, 'makhwapheni' refers to officer-in-charge, and 'bomshana' refers to children. In standard SiSwati language , the word 'makhwapheni' comes from 'likhwapha' which means 'armpit.' The prison officer-in-charge is called 'makhwaphweni' because of the short sticks those in her rank carry. These sticks are often put under their armpits.

'Bomshana' ${ }^{3}$ is a collective form used to describe nephews and nieces in the mainstream language. But the prisoners use the word to mean 'children.'

\section{b) Words borrowed from the English Language}

In the table below are examples of words loaned from the English language.

\begin{tabular}{|c|c|c|}
\hline Prison Code & SiSwati & English \\
\hline square & $\begin{array}{c}\text { umbhedze } \\
\text { kutsengisa }\end{array}$ & $\begin{array}{c}\text { bed } \\
\text { to sell }\end{array}$ \\
\hline
\end{tabular}

The prisoners have borrowed words like, square, supermarket, etc. from English. Again, these words are used differently from their original language. From the example, the word 'square' refers to a bed according to prison language, yet in the Standard variety a square is a shape. 'Supermarket' in the prison language does not mean a building where food is sold. It is a word the prisoners use for bartering 'their things.' If a prisoner, for instance, does not have Vaseline, she can ask from those who have. She will scoop some out of the jar and will pay with her share of chicken ${ }^{4}$ on Sunday. The more she asks, the more she will lose her share of chicken.

\section{c) Words borrowed from Afrikaans}

There are words that have been borrowed from the Afrikaans language. The examples in the table below show this:

\begin{tabular}{|c|c|c|}
\hline Prison Code & SiSwati & English \\
\hline $\begin{array}{l}\text { suiker } \\
\text { spana } \\
\text { skeif }\end{array}$ & $\begin{array}{c}\text { shukela } \\
\text { imisebenti yemalangeni } \\
\text { lugwayi }\end{array}$ & $\begin{array}{c}\text { sugar } \\
\text { menial work } \\
\text { cigarette }\end{array}$ \\
\hline
\end{tabular}

From the example above, 'suiker,' 'spana,' and 'skeif,'

3 It should be noted that this word could have also been borrowed from the local Tsotsi language hence its use resembles the way it is used in the Tsotsitaal.

4 Chicken is only eaten on Sundays. This is supposed to be the prisoners' best meal of the week. 
have been borrowed from Afrikaans. It should be noted that there is no difference in the way these words are used in the prison language and in the Standard variety.

d) There is only one word that has been borrowed from the Shangaan ${ }^{5}$ language. We have for example "kunyata. ${ }^{6}$ (See Table 5 in Appendix C). In Shangaan, this word means 'sister-in-law.' When it is used in Mawelawela, it refers to foreign immigrant prisoners regardless of their country of origin.

e) The other influence comes from Tsotsitaal. The Tsotsitaal lexical items used by these prisoners can be further divided into two. There are words that come from the universal Tsotsitaal and others that come from the local ${ }^{7}$ Tsotsitaal For example:

$\begin{array}{ll}\text { Universal Tsotsitaal } & \text { Local Tsotsitaal } \\ \text { magriza (grandmother) } & i \text {-dzo (bread) } \\ \text { mrava (bread) } & \text { rashu (shoes) } \\ i \text {-nkaw'za (cigarette) } & i \text {-lalaza (police vehicle) }\end{array}$

\section{Attitudinal Expression}

The table shows examples of prison terms expressing the prisoners' attitude to prison life.

\begin{tabular}{|c|c|c|}
\hline Prison Code & SiSwati & English \\
\hline sona & siboshwa & a prisoner \\
tona & tiboshwa & prisoners \\
mantjingelane & gadzi welijele & warder \\
tinkawu & emaphoyisa & police \\
mortuary & lijele & the prison \\
luhlata & sipinashi & spinach \\
\hline
\end{tabular}

The study revealed that women prisoners are bitter about the way they are treated by the warders and the prison authorities. They are referred to as 'sona' for singular or 'tona' for plural. 'Sona' and 'ton $a^{18}$ are absolute pronouns found in Class 4 in the SiSwati grammar. These words have connotations of criminal, jailer, law-breaker, prisoner, and jailbird. To be referred to in this way shows that the warders and the prison officers are not friendly at all towards the prisoners. These are words the prisoners would not like to be used on them. The fact that the prison, according to prisoners, is referred to as a 'mortuary' means that they are not given good care. Even the food they eat is not exciting. One of the complaints, for example, was that they are always served spinach and cabbage. These prisoners have termed spinach 'luhlata' and in SiSwati the literal meaning of this word is 'green.' The word has an attitudinal factor. They feel they are always given 'greens' because they are treated like animals and therefore deserve to eat such food most of the time.

The prisoners call the warders 'mantjingelane.' This is a derogative term for 'security officers.' The prisoners use this word to mean that the warders are always watching over them and therefore have taken over the work of security

5 The Shangaan language in question is the Shangaan spoken in Mozambique.

6 The Shangaan immigrants are fond of addressing every female 'kunyata.' 7 By local the researcher means SiSwati Tsotsitaal.

8 The prisoners have not originally coined these words. They are mainly used by the warders and prison officials when they talk about the prisoners or informally address them, so prisoners have adopted them too to address one another. guards. In Swaziland, having a security guard is still a quite new phenomenon. All along white people were the only ones who had security guards in Swaziland. The police, are called 'tinkawu.' This word in SiSwati means a type of wild animal that belongs to the biological group of monkeys. 'Tinkawu' are known to like staring at people. To the prisoners, since the police are always on the lookout for law-breakers, they resemble these animals. The use of such words denotes the prisoners' hatred for the police and warders. It should be noted that both terms are used derogatively.

\section{Conclusions}

The major purpose of the study was to investigate the lexical choices made by women prisoners in Swaziland which result in a different variety from that of mainstream society. The interviews revealed the prisoners' attitudes about prison life. They clip words and borrow others from English, Afrikaans, Shangaan and Tsotsitaal. It was also discovered that the prisoners use words metaphorically. The paper concludes that to prisoners this new variety is a social marker and using it separates them from the outside world.

One other important thing demonstrated in the study was that prisoners are able to code switch in contexts that suit them, using both their variety and the SiSwati Standard variety. For example, when they communicate among themselves, they are able to use their language, but when they interact with warders and prison officials, they switch to the Standard variety. Knowing both varieties enables them to hide their covert language from warders and prison officials. Knowing and being able to speak their own "prison" variety gives them a sense of belonging.

Drawing from the research it is in fact useful to argue that the prisoners are not accepted easily back into society once they are freed from prison. Society sees them as social outcasts and prisoners then revert to wrongdoing. The researcher believes that society should be taught that prisoners when detained in the process they are corrected of their unlawful activity. When they are out of prison it is society that needs to absorb them and help them to be members of society again.

Although the findings went beyond the researcher's expectations as the informants produced responses that one would not expect from their situation, (a) as women and (b) because they are a group that the researcher did not perceive would have a variety of their own.

\section{Appendices}

\section{Appendix A - Interview Questions}

1. How old are you?

2. Are you married?

3. What is your highest level of education? 
4. Now that you have been in prison for a long time, how do you feel about prison?

5. Is there a language that you use here when you speak among yourselves that is different from the language that you use at home?
6. When do you use these words?

7. Do you use the same language when you are addressing the warders or prison officials?

8. Which language do you use when addressing the prison officials or warders?

\section{Appendix B -- List of Words Prepared Prior to the Interview}

A) Body

\begin{tabular}{|c|c|c|c|c|}
\hline SiSwati & Prisoner's code & SiSwati & Prisoners' code & SiSwati \\
\hline & & Pmabhontisi & & mantji \\
& & sigwhebo & lolahlwe licala \\
tandla & & shukela & umsolwa \\
tibunu & & inyama yenkhomo & & kweca ejele \\
emehlo & & inyama yenkhukhu & umshushisi \\
emabele & & lisobho & ummeli \\
tinyawo & & cabbage & kucolelwa Silo \\
& & sipinashi & & kubaleka ejele \\
\hline
\end{tabular}

D) Prison Facilities

\begin{tabular}{|c|c|c|c|}
\hline SiSwati & Prisoners' code & SiSwati & Prisoners' code \\
\hline
\end{tabular}

E) Other Lexical Items
Appendix C - Lexical Variation between the SiSwati Standard Variety and the Mawelawela Prisoners' Code in Table Format

Table 1. Lexical items related to body parts.

\begin{tabular}{|c|c|c|}
\hline Prisoners' code & SiSwati & English \\
\hline back seat & tibunu & buttocks \\
parmalat & emabele & breasts \\
emahhulu & emehlo & eyes \\
tidladla & tandla & hands \\
\hline
\end{tabular}

Table 2. Lexical items related to meals.

\begin{tabular}{|c|c|c|}
\hline Prisoners' code & SiSwati & English \\
\hline i-dzo/mrava & sinkhwa & bread \\
libhontji & emabhontisi & beans \\
seiker & shukela & chicken \\
ligcemane & inyama yenkhukhu & beef \\
licashana & inyama yenkhomo & soup \\
sidimbidimbi & lisobho & spinach \\
luhlata & sipinashi & \\
\hline
\end{tabular}

Table 3. Lexical item related to relationships.

\begin{tabular}{|c|c|c|}
\hline Prisoners' code & SiSwati & English \\
\hline libhantinti & umyeni & husband \\
spotjovu & singani & boyfriend \\
magriza & gogo & grandmother \\
bomshana & children \\
mazero & bantwana & exashende \\
\hline
\end{tabular}


Table 4. Lexical items related to hygiene

\begin{tabular}{|c|c|c|}
\hline Prisoners' code & SiSwati & English \\
\hline splash & kugeza & to bath \\
six - nine & kuchama & to pee \\
skeif $/$ i-nkaw'za & lugwayi & cigarette \\
sihlahla $/$ i-zol & marijuana \\
imihosho & insangu & drugs \\
\hline
\end{tabular}

Table 5. Lexical items related to prison facilities

\begin{tabular}{|c|c|c|}
\hline Prisoners' code & SiSwati & English \\
\hline span, kofolo, job & imisebenti yemalangeni & menial work \\
i-lalaza & imotolo yemaphoyisa & police van \\
square & umbhedze & bed \\
bra, mantjingelane & gadzi wasejele & warder \\
makhwapheni & umphatsi welijele & officer-in-charge \\
tinkawu & emaphoyisa & police \\
mortuary & ejele & the prison \\
Ngarua & tiboshwa lesetinesikhatsi ejele & long-term servers \\
bo-Kunyata, bo-skoni & tiboshwa letingesiwo emaSwati & immigrant prisoners \\
\hline
\end{tabular}

Table 6. Lexical items related to court registers

\begin{tabular}{|c|c|c|}
\hline Prisoners' code & SiSwati & English \\
\hline madida & ummeli & lawyer \\
shu & umshushisi & prosecutor \\
sidikadika & kucolelwa Silo & parole \\
kujomba & kweca ejele & to escape from prison \\
uhociselwe & kukhululwa ejele & to be freed \\
bo-dlantji & tiboshwa lesetigwetjiwe & convicts \\
bo-toki & basolwa & the unconvicted \\
\hline
\end{tabular}

Table 7. Other lexical items.

\begin{tabular}{|c|c|c|}
\hline Prisoners' code & SiSwati & English \\
\hline inyuku & imali & money \\
i-supermarket & kutsengisa & to sell \\
headlines, first borns & timpimpi & those who spy on others \\
kushushula & kweba kudla & to steal food \\
hosi & esibhedlela & hospital \\
office & tindlu tekulala & dormitory \\
\hline
\end{tabular}

\section{REFERENCES}

[1] Johnson-Weiner, K.M. (1998) "Community Identity and Language Change in North American Anabaptist Communities" in Journal of Sociolinguistics, vol.2, No. 3, October 1998. Pp 375-394.

[2] Benton, P (1978) in http://dictionary.prisonwall.org.

[3] Labov, W. (1966) Social Stratification of English In New York City. Washington DC: Centre for Applied Linguistics.

[4] Labov, W. (1972) Sociolinguistic Patterns. Philadelphia: University of Pennsylvania.

[5] Borberly, A. (2005) 'Languages and Language Varieties: Comparative Research on the Linguistic Attitudes in Four Bilingual Minority Communities in Hungary,' In ESUKA-JEFUL 2011, 2-1: 41-55

[6] Wodak, R., \& Kotthof, H. (eds.) (1997) Communicating Gender in Context. Amsterdam: John Benjamins.
[7] Romaine, S. (1995) Bilingualism. Oxford: Oxford University Press.

[8] Milroy, L., \& Milroy, J. (1992) 'New Perspective in the Analysis of Sex Differentiation in Language,' in K. Bolton \& H. Kwok (eds.), Sociolinguistics Today: International Perspective. London and New York: Routledge. Pp 162-179.

[9] Finlayson, R. (1995) Women's language of respect: 'isihlonipho sabafazi'. In: R. Mesthrie (ed.), Language and Social History, pp. 140-154. Cape Town/ Johannesburg: David Philip.

[10] Holmes, J. (1995) Women Men and Politeness London: Longman.

[11] Mills, S. (2003) Gender and Politeness, Cambridge: Cambridge University Press.

[12] Fromkin, V.A., (ed): Curtiss, S., Hayes, B.P., Hyams, N., Keating, P.A., Keopman, H., Munro, P., Spontiche, D., Stabbler, P.E., Sterviade, D., Stowell, T, \& Szabolcsi, A. (2000) An Introduction to Linguistic Theory. United Kingdom: Blackwell Publishers.

[13] Saville-Troike (1982) Ethnography of Communication: An Introduction. Oxford: Basil Blackwell. 
[14] Macelhearn in www.macelhearn.com/cmc.html.

[15] Milroy, L. (1980) Language and Social Networks. Oxford: Basil Blackwell.

[16] Deumert, A., \& Mesthrie, R. (2000) 'Language Variation and Change' in Mesthrie, R., Swann, J., Deumert, A., \& Leap, W. (eds.) Introducing Sociolinguistics. Edinburgh: Edinburgh University Press. Pp 114-147.

[17] Mesthrie, R. (2000) 'Language Contact 2: Pidgins, Creoles and New Englishes" in Mesthrie, R., Swann, J., Deumert, A., \& Leap, W. (eds.) Introducing Sociolinguistics. Edinburgh: Edinburgh University Press. Pp 279-315.

[18] Coupland, N., Coupland, J, and Giles, H. (1991) Language,
Society and the Elderly. Cambridge, Massachusetts: Blackwell.

[19] Scotton, C, \& Ury, W. (1977) 'Bilingual Strategies: The Social Function of Code Switching,' in International Journal of the Sociology of Language. 13: 5-20.

[20] Finlayson, R. \& Slabbert, S. (1997) "We just Mix: Code Switching in a South African Township, in International Journal for the Sociology of Language 125: 65-98.

[21] Trudgil, P. (1995) Sociolinguistics: An introduction to Language and Society. London: Penguin.

[22] Aremo, B. (1997) An Introduction To English Sentences. Nigeria: Caltop Publications Ltd. 